\title{
Study of the Impact of Organic Manures and Biofertilizers on growth of Phaseolus aureus Roxb.
}

\author{
Chhaya Bhalshankar@
}

New Arts Commerce and Science College, Shevgaon, Dist.-Ahmednagar, M.S. (India)

Article history:- Received: 15 Jun 2020; Revised: 20 Sep 2020; Accepted: 1 Oct 2020; Published online: 22 Oct 2020

\begin{abstract}
Weeds are wild plants growing where they are not wanted, and they compete with the cultivated crop for nutrition. Though they are seen as agricultural waste throughout the year, they are rich sources of nutrients. They grow in abundance during the rainy season, but as the season ends these biomasses get wasted. In the present investigation, Tephrosia hamiltonii Drumm belonging to family Fabaceae, and Achyranthes aspera L. belonging to the family Amaranthaceae were used as a nutrient source to develop crop Phaseolus aureus Roxb. Weed manures, Vermicompost and Compost, were prepared by using weeds T. hamiltonii Drumm and A. aspera L. in 1:1 proportion. Chemical analysis of weed and weed manures were done before administering it into the soil. Neem cake was also used as one of the organic manures. In the experiment, a single dose of biofertilizers Azotobacter and Phosphate solubilizing bacteria were mixed with Weed Vermicompost, Weed Compost and Neem cake; and in one of the treatments, only biofertilizers were used indouble dose. Treatments were given to the crop as ATVB, ATCB, NCB, BioD, NPK, and Control in a randomized block design of experimental plot size $1.5 X 1.5 \mathrm{~m}$. The use of chemical pesticides or fertilizers was completely avoided except for NPK treatment plots. Single plant analysis of pulse crop P. aureus Roxb. was done. Observations were recorded in the forms of fresh weight and dry weight of root, stem, leaves, leaf (4th number), and legumes. Total fresh yield $\left(\mathrm{kg} \mathrm{ha}^{-1}\right)$, $\mathrm{DM}\left(\mathrm{kg} \mathrm{ha}^{-1}\right)$ increase over control, and Nitrogen efficiency ratio were recorded. Results showed that \% DM (an increase over control) and DM kg ha-1 recorded highest in ATVB treatment and the highest $\mathrm{N}$ efficiency ratio was in BioD. The present investigation emphasized reducing the input cost of the farm products along with protection of the environment and natural resources.
\end{abstract}

Keywords: Biofertilizer, Neemcake, Organic agriculture, P. aureus, Weed compost, Weed Vermicompost.

$\checkmark$ Corresponding author, email: bhalshankarchhaya@gmail.com

\section{Introduction}

Recent agricultural trends are focused on both reducing the usage of inorganic fertilizers by using organic manure and applying biofertilizers such as vermicompost and phosphatic biofertilizers [1]. Microbial activities play a key role in agriculture because they are significant in the movement and availability of minerals required for plant growth and ultimately lower the use of chemical fertilizers [2]. The maintenance of nutrients in the soil is most important for healthy plant growth [3]. Biofertilizers enhance soil health and crop yield. They improve fertility of soil, nutrient uptake, decomposition of crop residue, and microbial diversity of soil. They also reduce the requirement of chemical fertilizers [4]. The use of excessive chemical fertilizer, however, causes hazardous effects on the soil, leading to serious problems; thus, biofertilizers are important alternative sources of nutrients. They are biologically active microorganisms, like bacteria, algae, fungi; they can provide nutrients to crops [5, 6]. Among Biofertilizers, beneficial bacteria are Azotobacter, Azospirillum, Rhizobium, symbiotic fungi Mycorrhizae; they are essential in crop production. Biofertilizers improve plants' resistance to an unfavorable environment [7]. The biological manure helps to increase crop yields, and also plays a vital role in the nutrient accessibility in soil by improving the physical, chemical, and biological structure of soil, and it enhances the utilization of applied fertilizers [8]. In developing countries, residue management is very important as the amount of nutrients in crop residue is several times higher than the quantities of these nutrients applied as high cost fertilizer [9].

Weed plants compete with the agricultural crops; they cause a tremendous reduction in crop yields and increase their production costs. Several scientists have estimated such losses in crop yields in different parts of India. A very broad-based 
average of these estimates show that weeds reduced productivity of wheat by $15-30 \%$, rice by $30-35 \%$, and maize, sorghum, pulses and oilseeds by $18-85 \%$ each. Many cases of complete crop failure due to weeds particularly in upland rice and vegetable crops were recorded $[10,11,12]$. T. hamiltonii Drumm. and $A$. aspera $\mathrm{L}$. are the weed plants used in the present study. The present study emphasized conversion and utilization of weeds beneficially by using them for the preparation of compost and vermicompost. Neem cake is a residue left after the extraction of neem oil and used as an organic fertilizer. With the utilization of these organic manuresalong with biofertilizers like Azotobacter and Phosphate solubilizing bacteria for the cultivation of Pulse crop P. aureus Roxb. belonging to the family Fabaceae.

We can minimize the cost of production, increase output per hectare by using organic manures like compost, vermicompost prepared from weed biomass, Neem cake, and biofertilizers for the production of crops and for sustainable agriculture.

\section{Material and Methods}

The experiment was conducted during March 2008. A summer variety of $P$. aureus Roxb. was cultivated at college campus of New Arts, Commerce and Science College, Shevgaon District Ahmednagar, (Maharashtra), India. Shevgaon extends between 19013 North latitude to 19035 North latitude and between 75001 East longitudes to 75037 East longitude.

\section{Weed collection and preparation of manures}

The fresh vegetation of weeds i.e. Aghada (A. aspera L.) and Unhali (T. hamiltonii Drumm.) were collected from different localities and chopped into small pieces $(2-3 \mathrm{~cm})$ by locally available iron cutter. Equal amount $\left(6944+6944 \mathrm{~kg} \mathrm{ha}^{-1}\right)$ 1:1 proportion mixture of weed pieces were used for the preparation of compost and vermicompost. To prepare compost this material was placed into pit $(90 \times 90 \times 90 \mathrm{~cm})$ and then added cow dung, soil and weed plant material layer by layer and sprinkled with water per requirement. Finally, the compost pit was sealed with dung-mud mixture to prevent loss of heat and moisture. After partial decomposition first turning was given after 15 days for homogeneous decomposition, subsequent turnings were given after every 15 days interval. Sufficient water was sprinkled to maintain moisture. Finally, amorphous, dark brown, well fermented compost was obtained within 70 days. Fresh weight of Compost obtained from pit was $33 \mathrm{~kg}$. Same procedure was applied for vermicomposting, only with the addition of the worms in the pits after 15 days (Worms' variety Eudriluseugeniae and Iceniafoetida). Identification of earthworms was done by the method prescribed in Fauna of India and Adjacent countries [13]. The prepared vermicompost was used for field trials. Fresh weight of vermicompost obtained from pit was $32 \mathrm{~kg}$. The uniformly mixed samples $(100 \mathrm{~g})$ were collected immediately from the pit for nutrient analyses. Chemical analyses of weeds and weed manures and Neem cake were done using oven dried and pulverized powder of samples. All the manures compost, vermicompost and neemcake $\left(1000 \mathrm{~kg} \mathrm{ha}{ }^{-1}\right)$ were mixed with biofertilizer Azotobacter and phosphate solubilizing bacteria at the rate $25 \mathrm{~kg} \mathrm{ha}^{-1}$ (recommended dose); and only Biofertilizer double dose treatment $50 \mathrm{~kg} \mathrm{ha}^{-1}$ in two split doses were applied to appropriate plots except chemical fertilizer (NPK) plots. The Mung (P. aureus Roxb.) Variety “Raj Biotech" Balwan R.J. Biotech, Pvt Ltd. Siddharth Arcade, Station Road, Aurangabad was sown in the research plots of size $1.5 \times 1.5 \mathrm{~m}$. at the rate of $20 \mathrm{~kg} \mathrm{ha}^{-1}$.

\section{Application of Inorganic Fertilizers}

The inorganic fertilizers were supplied to the experimental plots as Nitrogen $(\mathrm{N})$, Phosphorus $(\mathrm{P})$ and Potassium (K) through urea, single super phosphate (SSP) and muriate of potash at the rate of $25 \mathrm{~kg} \mathrm{~N}, 50 \mathrm{~kg}$ P and ' 0 ' K kg ha-1 (25:50:0) only for fertilizer treatment plots. Entire amount of $\mathrm{P}_{2} \mathrm{O}_{5}$ and $\mathrm{K}_{2} \mathrm{O}$ and $\mathrm{N}$ was applied at the time of sowing. The crop supplemented with irrigation during periods of growth and whenever necessary weeding was done. Use of insecticides and pesticides was completely avoided.

Seeds were planted in rows at a distance $30 \mathrm{~cm} \times 10$ $\mathrm{cm}$. Soil was murum so the crop was grown under frequent irrigation after each 8-10 days. Sample from each plot was brought into laboratory chopped into 3-4 $\mathrm{cm}$ pieces. Measured amount of biomass was kept in digital electrical oven separately in preweighted tray at $95 \pm 5^{\circ} \mathrm{C}$ for 48 hours or more till constant weight. Weight of dried samples were reported as DM. Results were used to calculate $\% \mathrm{DM}$, DM Kgha ${ }^{-1}$, increase over control and Nitrogen efficiency ratio of crop. 


\section{Results}

Table 1. Analyses of weeds administered in experimental plots through compost and vermicompost weed manures.

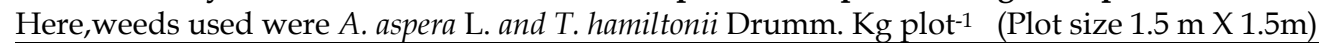

\begin{tabular}{|c|c|c|c|c|c|c|c|c|c|c|c|}
\hline \multirow[b]{2}{*}{ Weed Name } & \multicolumn{2}{|c|}{ Fresh weight } & \multicolumn{2}{|c|}{$\mathrm{DM}$} & \multicolumn{2}{|c|}{ Nitrogen } & \multicolumn{4}{|c|}{$\%$} & \multirow[b]{2}{*}{$\mathrm{C}: \mathrm{N}$} \\
\hline & $\begin{array}{c}\mathrm{Kg} \\
\text { plot }^{-1}\end{array}$ & $\begin{array}{c}\mathrm{Kg} \\
\mathrm{ha}^{-1}\end{array}$ & $\begin{array}{c}\% \\
\mathrm{DM} \\
\end{array}$ & Kg ha-1 & $\% \mathrm{~N}$ & $\mathrm{Kg} \mathrm{ha}^{-1}$ & Ash & $\mathrm{P}$ & K & $\mathrm{C}$ & \\
\hline Achyranthes & 1.56 & 6944 & 19.29 & 1339.50 & 2.03 & 27.19 & 17.43 & 0.123 & 0.43 & 10.11 & 4.99 \\
\hline Tephrosia & 1.56 & 6944 & 22.40 & 1555.46 & 1.94 & 30.18 & 18.57 & 0.115 & 0.51 & 10.77 & 5.54 \\
\hline
\end{tabular}

Table 2.Analyses of weed manure and Neem cake amendment along with biofertilizer. Here, ATVB=Achyranthes, Tephrosia vermicompost mixed with Biofertilizer single dose, ATCB=Achyranthes, Tephrosia compost along with Biofertilizer single dose, NC=Neem cake along with Biofertilizer single dose

\begin{tabular}{|c|c|c|c|c|c|c|c|c|c|}
\hline \multirow[t]{2}{*}{ Treat ments } & \multirow{2}{*}{$\begin{array}{l}\text { Fresh } \\
\text { weight } \\
\text { Kg plot }^{-1}\end{array}$} & \multirow{2}{*}{$\begin{array}{l}\text { Fresh } \\
\text { weight } \\
\text { Kg ha-1 }^{-1}\end{array}$} & \multicolumn{2}{|l|}{$\mathrm{DM}$} & \multicolumn{2}{|l|}{$\mathrm{N}$} & \multicolumn{3}{|l|}{$\%$} \\
\hline & & & $\%$ & $\mathrm{~kg} \mathrm{hect-1}$ & $\% \mathrm{~N}$ & $\mathrm{Kg}_{\mathrm{gect}}{ }^{-1}$ & $\mathrm{P}$ & K & $\mathrm{Ca}$ \\
\hline ATVB & 2.00 & 8889 & 67.21 & 5974.30 & 0.42 & $25+4.485$ & 0.13 & 0.14 & 3.6 \\
\hline АТCB & 2.06 & 9169 & 65.07 & 5966.27 & 0.50 & $30+4.485$ & 0.12 & 0.16 & 4.3 \\
\hline $\mathrm{NCB}$ & 0.23 & 1000 & 97.94 & 0979.40 & 1.96 & $19+4.485$ & 0.81 & 0.48 & 0.9 \\
\hline
\end{tabular}

(Amount of Nitrogen fixed by single dose of biofertilizer is $4.485 \mathrm{~kg} \mathrm{ha}^{-1}$ as according to $\mathrm{N}$ balance method[14]). These values added in $\mathrm{N} \mathrm{kg} \mathrm{ha}^{-1}$ of other treatments and amount of $\mathrm{N} \mathrm{kg} \mathrm{ha}^{-1}$ fixed by Azotobacter biofertilizer double dose was $\left.8.97 \mathrm{~kg} \mathrm{ha}^{-1}\right)$.

Table 3. C:N ratio of organic amendments. Here, ATV=Achyranthes, Tephrosia vermicompost, ATC=Achyranthes,

Tephrosia compost, NC=Neem cake

\begin{tabular}{lllll}
\hline \multirow{2}{*}{ Treatments } & \multicolumn{3}{c}{$\%$} & $\mathrm{~N}$ \\
\cline { 2 - 5 } & Ash & $\mathrm{C}$ & $\mathrm{N}$ \\
\hline ATV & 32.00 & 18.56 & 0.42 & 44.56 \\
ATC & 36.50 & 21.17 & 0.50 & 42.36 \\
NC & 74.93 & 43.46 & 1.96 & 22.17 \\
\hline
\end{tabular}

Table 4. Fresh wt and DM analyses of Single Plant of Phaseolus (at 56 DAS). Here, ATVB=Achyranthes, Tephrosia vermicompost mixed with Biofertilizer single dose, $\mathrm{ATCB}=$ Achyranthes, Tephrosia compost mixed with Biofertilizer single dose, $\mathrm{NC}=\mathrm{Neem}$ cake along with Biofertilizer single dose. BioD=Biofertilizer double dose, NPK=Inorganic fertilizer, $\mathrm{CON}=$ Control. (DAS=Days after sowing)

\begin{tabular}{|c|c|c|c|c|c|c|c|c|c|c|c|c|}
\hline \multirow[t]{2}{*}{ Treatment } & \multicolumn{6}{|c|}{ Plant Fresh wt in gm } & \multicolumn{6}{|c|}{ DM in $\mathrm{gm}$} \\
\hline & Root & Stem & Leaves & $\begin{array}{l}\text { 4th } \\
\text { leaf }\end{array}$ & $\begin{array}{l}\text { Total } \\
\text { plant }\end{array}$ & Legume & Root & Stem & Leaves & $\begin{array}{l}\text { 4th } \\
\text { leaf }\end{array}$ & $\begin{array}{l}\text { Total } \\
\text { plant }\end{array}$ & Legume \\
\hline ATVB & 0.49 & 4.89 & 11.29 & 3.59 & 22.55 & 5.83 & 0.21 & 1.44 & 2.99 & 0.82 & 7.99 & 2.71 \\
\hline ATCB & 0.48 & 3.93 & 09.79 & 2.57 & 18.53 & 4.21 & 0.19 & 1.17 & 2.77 & 0.60 & 6.47 & 3.03 \\
\hline BioD & 0.60 & 5.29 & 12.87 & 3.92 & 24.37 & 5.44 & 0.24 & 1.40 & 3.25 & 0.90 & 8.30 & 3.49 \\
\hline NCB & 0.39 & 2.75 & 06.79 & 1.66 & 12.71 & 2.65 & 0.13 & 0.74 & 1.80 & 0.43 & 4.20 & 1.67 \\
\hline NPK & 0.51 & 3.70 & 08.38 & 2.15 & 15.09 & 2.63 & 0.20 & 1.08 & 2.21 & 0.53 & 4.76 & 1.60 \\
\hline $\mathrm{CON}$ & 0.19 & 1.82 & 03.49 & 1.14 & 07.26 & 1.72 & 0.08 & 0.47 & 1.02 & 0.27 & 2.33 & 1.41 \\
\hline S.E & 0.06 & 0.53 & 1.37 & 0.44 & 2.61 & 0.68 & 0.02 & 0.16 & 0.34 & 0.10 & 0.95 & 0.36 \\
\hline C.D. & 0.12 & 1.13 & 2.92 & 0.94 & 5.56 & 1.45 & 0.05 & 0.33 & 0.73 & 0.21 & 2.02 & 0.76 \\
\hline
\end{tabular}

Table 5. Increase over control of total biomass and Nitrogen efficiency ratio (73DAS). It is the ratio of the crop Nitrogen uptake to the total input of Nitrogen fertilizer.

\begin{tabular}{llccccccccc}
\hline & \multicolumn{4}{c}{ FRESH WT $\%$} & \multicolumn{3}{c}{ DRY WT \% } & \multicolumn{3}{c}{ N Efficiency Ratio } \\
\cline { 2 - 10 } Treatment & $\begin{array}{c}\text { FW } \\
\text { Kg ha-1 }^{-1}\end{array}$ & $\begin{array}{c}\text { Increase } \\
\text { Over Con }\end{array}$ & $\begin{array}{c}\text { Increase } \\
\text { Over Con }\end{array}$ & $\begin{array}{c}\text { DM } \\
\text { Kg ha-1 }\end{array}$ & $\begin{array}{c}\text { Increase } \\
\text { over con }\end{array}$ & $\begin{array}{c}\text { Increase } \\
\text { over con }\end{array}$ & Input N & Fresh & Dry \\
\hline ATVB & 4685 & 1676 & 55.71 & 1660 & 695 & 72.02 & 29.485 & 56.85 & 23.57 \\
ATCB & 4312 & 1303 & 43.31 & 1505 & 540 & 55.96 & 34.485 & 37.79 & 15.66 \\
BioD & 4136 & 1127 & 37.44 & 1409 & 444 & 46.01 & 8.970 & 125.60 & 49.50 \\
NCB & 3480 & 0471 & 15.64 & 1150 & 185 & 19.17 & 23.485 & 20.04 & 7.88 \\
NPK & 3380 & 0371 & 12.33 & 1066 & 101 & 10.47 & 25.000 & 14.84 & 4.04 \\
CON & 3009 & 0000 & 00.00 & 965 & 000 & 00.00 & 0.00 & 00.00 & 00.00 \\
\hline
\end{tabular}


Analyses of weeds were done on dry matter basis. Observations of weed analyses are recorded in the

Table 1. Fresh weightswere used, $1.56 \mathrm{~kg} \mathrm{plot}^{-1}(6944$ $\left.\mathrm{kg} \mathrm{ha}^{-1}\right)$ of each weed, for preparations of manures. $\%$ DM of Tephrosia weed was higher (22.4), followed by Achyranthes (19.29). The DM kg ha-1 of Tephrosia weed was higher (1555.46) followed by Achyranthes weed (1339.50). \% N was higher in Achyranthes (2.03) followed by Tephrosia (1.94) (Tephrosia weed was collected from comparatively non fertile land and Achyranthes from fertile land with ample domestic waste nearby. So, Nitrogen percent of Tephrosia was less than Achyranthes though it is leguminous weed). $\mathrm{N} \mathrm{kg} \mathrm{ha}^{-1}$ of Tephrosia weed was higher (30.18) it was followed by Achyranthes (27.19). \% Ash of Tephrosia weed was higher (18.57); it was followed by Achyranthes (17.43). \% Pwas higher in Achyranthes (0.123) followed by Tephrosia (0.115). \% K was higher in Tephrosia (0.51) followed by Achyranthes (0.43). \% Cof Tephrosia weed was higher (10.77); it was followed by Achyranthes (10.11). C:N ratio of Tephrosia weed was higher (5.54), and it was followed by Achyranthes (4.99).

Analyses of Achyranthes and Tephrosia weed manure and Neemcake were done; it is presented in Table 2. Fresh weight of weed compost (ATC) was administered at the rate of $2.06 \mathrm{~kg} \mathrm{plot}^{-1}\left(9169 \mathrm{~kg} \mathrm{ha}^{-}\right.$ $\left.{ }^{1}\right)$ and weed Vermicompost (ATV) was added at the rate of $2.00 \mathrm{~kg} \mathrm{plot}^{-1}\left(8889 \mathrm{~kg} \mathrm{ha}^{-1}\right)$. Fresh weight of Neem cake (NC) was used at the rate of $0.23 \mathrm{~kg}$ plot ${ }^{1}$ (1000 kg ha-1). All the manures treatment was mixed with single dose of biofertilizer i.e. $25 \mathrm{~kg} \mathrm{ha}^{-1}$. Double dose of biofertilizer $50 \mathrm{~kg} \mathrm{ha}^{-1}$ was given to the biofertilizer treatment (BioD). \% DM of ATV (on $211^{\text {th }}$ day) was $67.21 \%$; it was followed by ATC (on $211^{\text {th }}$ day) was $65.07 \%$ and Neemcake $97.94 \%$. DM kg ha-1 was highest in Vermicompost (5974.30) followed by Compost (5966.27) and lowest in Neemcake (979.40). \% N and $\mathrm{N} \mathrm{kg} \mathrm{ha-1} \mathrm{was} \mathrm{highest}$ in ATCB $(0.5 \%, 30 \mathrm{~kg})$ followed by ATVB $(0.42 \%, 25$ $\mathrm{kg})$ and NCB $(1.96 \%, 19 \mathrm{~kg})$. Single dose of biofertilizer fixed $4.485 \mathrm{Nkg} \mathrm{ha}^{-1}$; so, input of $\mathrm{N}$ was 29.485 for ATVB, 34.485 for ATCB and 23.485 for NCB. \%Phosphorus recorded highest in Neem cake $(0.81)$ and \% Potassium in Neemcake (0.48); and \% Ca was highest in ATC (4.3).

Amount of Nitrogen fixed by single dose (recommended dose) of biofertilizer was $4.485 \mathrm{~kg}$ ha1 and amount of $\mathrm{N} \mathrm{kg} \mathrm{ha}^{-1}$ fixed by Azotobacter biofertilizer double dose was $8.97 \mathrm{~kg}^{\mathrm{ha}}{ }^{-1}$ in according to $\mathrm{N}$ balance method [14]. As per Table 3, $\%$ ash $\% \mathrm{C}$ and $\% \mathrm{~N}$ were highest in NC $(74.93,43.46$ and 1.96 , respectively) followed by ATC $(36.5,21.17$, $\& 0.5)$ and lowest in $\operatorname{ATV}(32,18.56 \& 0.42)$. C:N ratio was highest in ATV (44.56), followed by ATC (42.36) lowest in Neemcake (22.17).

In Table 4, Analyses of Fresh weight and Dry weight of single plantare presented. Fresh weight of root was highest in BioD (0.60) followed by NPK, ATVB, ATCB, NCB and lowest in the CON (0.19), statistically significant in all the treatments. The fresh weight of stem leaves and $4^{\text {th }}$ leaf and total plant was highest in BioD followed by ATVB, ATCB, NPK, NCB and lowest in the CON, FW of stem and total plant statistically not significant in NCB. FW of legume was highest in ATVB (5.83) followed by BioD, ATCB, NCB, NPK and lowest in CON (1.72), statistically significant in all the treatments except in $\mathrm{NCB}$ and NPK. The DM of root was highest in BioD (0.24) followed by ATVB, NPK, ATCB, NCB and lowest in the CON (0.08), statistically significant in all the treatments. DM of stemwas highest in ATVB (1.44) followed by BioD, ATCB, NPK, NCB and lowest in CON (0.47), statistically significant in all the treatments except in NCB. DM of leaves, $4^{\text {th }}$ leaf and total plant was highest in BioD followed by ATVB, ATCB, NPK, NCB and lowest in CON treatments, statistically not significant in NCB for $4^{\text {th }}$ leaf and total plant. DM of legume was highest in BioD (3.49) followed by ATCB, ATVB, NCB, NPK and lowest in CON (1.41), statistically not significant in NCB and NPK treatments.

In Table 5, Percent increase over control and nitrogen efficiency ratio is presented. The percent increase over control in Phaseolus for fresh weight was found highest in ATVB (55.71) followed by ATCB (43.31), BioD (37.44), NCB (15.64), and minimum in NPK (12.33). Similarly, dry matter percentage $(\mathrm{DM} \%)$ was found maximum with the treatment ATVB (72.02) followed by ATCB (55.96), BioD (46.01), NCB (19.17) and minimum in NPK (10.47).DM kg ha-1 recorded highest in ATVB (1660) followed by ATCB, BioD, NCB, NPK and lowest in CON (965), statistically significant in ATVB, ATCB, BioD, but statistically not significant in NPK and NCB. The nitrogen efficiency ratio for fresh weight was found highest in BioD (125.60) followed by ATVB (56.85), ATCB (37.79), NCB (20.04) and lowest 
in NPK (14.84). Similarly, the nitrogen efficiency ratio for Dry matter (DM) was found highest in BioD (49.50) followed by ATVB (23.57), ATCB (15.66), NCB (7.88) and lowest in NPK (4.04). Highest Fresh weight and DM kg ha-1 was recorded in Treatment ATVB.

\section{Discussion}

Azotobacter treated seedlings of knolkhol showed the highest whole plant weight [15]. Biofertilizers such as Azotobacter, Azospirillum, PSB, and a mixture of $\mathrm{Aza}+\mathrm{Azo}+\mathrm{PSB}$ were administered to crops which showed the increased plant fresh weight, dry weight [16]. Similar results showing fresh weight and dry weight of BioD treatment was recorded highest at 56 DAS. Combined inoculation of soybean by symbiotic bacteria improved the dry weight of soybean [17]. Vermicompost and phosphate biofertilizer showed improved growth and yield in Anise (Pimpinella anisum L) [1]. Vermicompost and PSB when applied together was found helpful in developing production and yield in anise [18]. Azotobacter increases the production of agriculture crop plants by $10-12 \%$. Azotobacter can also improve growth and grain yield in wheat crops. Azotobacter act as one of the vital biofertilizers in the case of rice and some cereals could be applied by seed dipping and seedling root dipping methods [19]. Maize hybrid seed priming with Azotobacter showed the highest grain yield (7.01 ton/ha) and DM accumulation (2019 gr / m2) in treatment compound SC-434 [20]. Panchgavyawas found to contribute to better growth and yield of Pisum sativum as compared to NPK [21].

In biochemical analyses of the total biomass of plant, Nitrogen, and total crude protein was recorded highest in ATVB [22]. The findings of the present experiment showed that Fresh weight and Dry weight was recorded highest in Biofertilizer double dose at 56 DAS. But at harvesting 73 DAS maximum Fresh and Dry Yield was recorded highest in Weed vermicompost + Biofertilizer Azotobacter and Phosphate solubilizing bacteria treatment (ATVB).

\section{Conclusion}

The results of this investigation concluded that weed vermicompost, weed compost along with a single dose of biofertilizer and biofertilizer double dose can effectively be used as a nutrient source to increase crop yield and soil fertility. Weed manures and
Neem Cake with biofertilizers worked more efficiently as compared to the chemical fertilizers (NPK) to improving the quality of the crop; it could reduce the input cost of the farm produce as well in addition to protecting the environment and natural resources.

\section{Author's Contribution}

$\mathrm{CB}$ is responsible for all the data collection, conceptualization, writing - original draft preparation, review \&editing the final draft of the manuscript. CB read and approved the final manuscript.

\section{Competing Interests}

No competing interests

\section{Funding}

The author(s) declared that no grants supported this work.

\section{Acknowledgments}

I express my deep sense of gratitude to my respected teacher and research guide Late Capt. Dr. Bharati Jadhav (retired professor), Department of Botany; Dr. Babasaheb Ambedkar Marathwada University, Aurangabad. I express my deep sense of gratitude to my respected institute Ahmednagar Jilha Maratha Vidya Prasarak Samaj's Management for their continuous encouragement.

\section{Ethical Approval and Consent}

Not applicable.

\section{References:}

1. Darzi MT, Hadi MH, Rejali F. Effects of vermicompost and phosphate biofertilizer application on yield and yield components in Anise (Pimpinella anisum L.). Iranian Journal of Medicinal and Aromatic Plants. 2011;26(4).

2. Verma S, Singh A, Pradhan SS, Singh RK, Singh JP. Bioefficacy of organic formulations on crop production-A review. International Journal of Current Microbiology and Applied Sciences. 2017;6(5):648-65. https:// doi.org/ 10.20546/ ijcmas. 2017.605.075

3. Devi V, Sumathy VJ. Production of biofertilizer from fruit waste. European journal of pharmaceutical and medical research. 2017;4(9):436-43.

4. Singh M, Dotaniya ML, Mishra A, Dotaniya CK, Regar KL, Lata M. Role of biofertilizers in conservation agriculture. InConservation Agriculture 2016 (pp. 113-134). Springer, Singapore.https://doi.org/10.1007/978-981-10-2558-7_4

5. Javoreková S, Maková J, Medo J, Kovácsová S, Charousová I, Horák J. Effect of bio-fertilizers application on microbial diversity and physiological profiling of microorganisms in arable soil. Eurasian Journal of Soil Science. 2015;4(1):54. https://doi.org/10.18393/ejss.07093

6. Rao DL, Balachandar D, Thakuria D. Soil biotechnology and sustainable agricultural intensification. Indian Journal of Fertilisers. 2015 Oct;11:87-105. 
7. Sneha S, Anitha B, Sahair RA, Raghu N, Gopenath TS, Chandrashekrappa GK, Basalingappa KM. Biofertilizer for crop production and soil fertility. Acad J Agric Res. 2018;6(8):299-306.

8. Mercy S, Mubsira BS, Jenifer I. Application of different fruit peels formulations as a natural fertilizer for plant growth. Int J SciTechnol Res. 2014 Jan 25;3(1):300-7.

9. Singh H. Effect of crop residue management on microbial biomass accumulation in the soil. Current science (Bangalore). 1993;65(6):487-8.

10. Mukhopadhyay SK. Emerging problems and advances in weed management. InPresidential Address, Agriculture Section, Indian Science Congress held at Baroda 1992.

11. Jain NK, Choubey SD. Weed control in Soyabean. Ind. J. Weed Sci. 1969;1(1):5-9.

12. Friesen GH, Korwer GR. Weed management for dry land crops. Weed Res. 1983;23:365-71. https://doi.org/10.1111 /j.1365-3180.1983.tb00560.x

13. Julka JM, India. ZS of.The fauna of India and the adjacent countries. Calcutta: Zoological Survey of India; 1988.

14. Peoples MB, Herridge DF. Nitrogen fixation by legumes in tropical and subtropical agriculture. InAdvances in agronomy 1990 Jan 1 (Vol. 44, pp. 155-223). Academic Press. https://doi.org/10.1016/S0065-2113(08)60822-6

15. Sharma JP, Rattan P, Kumar S. Response of vegetable crops to use of integrated nutrient management practices. ISABB Journal of Food and Agricultural Sciences. 2012 Jan 31;2(1):159.

16. Patel HD, Krishnamurthy R, Azeez MA. Effect of biofertilizer on growth, yield and bioactive component of Plumbago zeylanica (Lead Wort). Journal of Agricultural Science. 2016;8(5). https://doi.org/10.5539/jas.v8n5p141

17. Rosas SB, Rovera M, Andres JA, Correa NS. Effect of phosphorous solubilizing bacteria on the rhizobia-legume simbiosis. InFirst International Meeting on Microbial Phosphate Solubilization 2007 (pp. 125-128). Springer, Dordrecht. https://doi.org/10.1007/978-1-4020-5765-6_17

18. Darzi MT, Seyedhadi MH, Rejali F. Effects of the application of vermicompost and phosphate solubilizing bacterium on the morphological traits and seed yield of anise (Pimpinella anisumL.). Journal of Medicinal Plants Research. 2012 Jan 31;6(2):215-9. https://doi.org/10.5897/JMPR11.949

19. Shridhar BS. Review: Nitrogen fixing microorganisms. Int J Microbiol Res. 2012;3(1):46-52.

20. Sharifi RS, Khavazi K. Effects of seed priming with Plant Growth Promoting Rhizobacteria (PGPR) on yield and yield attributes of maize (Zea mays L.) hybrids. Journal of Food, Agriculture \& Environment. 2011;9(3/4 part 1):496-500.

21. Bhusare BP, Kulkarni AA (2017) Studies on Comparative Effect of NPK and Panchagavya on Growth and Yield of Pisumsativum L. Flora and Fauna 23:341-344.

22. Bhalshankar CK, Ahire MD. Integrated Nutrient Management of Phaseolus Aureus Roxb. by Using Weed Manures and Biofertilizers [Internet]. Scholar World-International Refereed Multidisciplinary Journal of Contemporary Research; 2016 [cited 2020 Jan 2]. Available from: http://irmjcr. scholarsworld.net/index.html\#Archive?archiveId=62317036 09671680 